\title{
On the Studies of Reactivity of Pulps for Acetylation.
}

\section{Iodine Adsorption on Pulps}

Saburo Ishikawa

The use of idodine adsorption techniques to appreciate the acetylation reactivity of pulps are described. The amounts of iodine adsorbed on pulps are different by its circumstances (water or acetic acid), concentration under which adsorption takés place and pulps.

When pulps are pretreated in hot acetic acid before iodine adsorption, the amounts of iodine adsorbed in acetic acid are increased following by Sakurada's equation $x=k Z^{m}: x:$ amounts of iodine adsorbed, $Z$ : time of treatment in min., $k, m:$ constant. For high reactive pulps $m$ was small and $k$ was high, but for low reactive one $m$ and $k$ were reverse respectively.

But when the time of pretreatment in acetic acid are prolonged, then the decreasing of iodine adsorbed takes place as well as sulphuric acid adsorption which was reported by previous papers. This decreasing of iodine adsorption may depend upon the growing of some new organizations which consist of some cross-linking and crystallization of cellulose chain which degraded during prolonged pretreatment. Moreov er, it seems that this new organizations may reduce the reactivity of pulps for acetylation.

\begin{tabular}{|c|c|c|}
\hline 正 誤 & 9 月号 p. 455 & 「光電式測定器」 \\
\hline 頁 & 位 置 & 䛊 \\
\hline 464 & 有一中 & $\int_{x=-\frac{a}{2}}^{x=0} \delta d x=0.398 a^{2}$ \\
\hline 465 & $\begin{array}{c}\text { 右一上 } \\
\prime \prime\end{array}$ & $\begin{array}{l}\text { Fig 25. } x>a \quad y>a \\
\delta \text { 中心の軌跡 }\end{array}$ \\
\hline " & 有一中 & $A \mathrm{t}-A \mathrm{c}=4 \mathrm{~s}$ \\
\hline " & " & 表面の粗が \\
\hline$\prime \prime$ & 在一下 & この测定で \\
\hline$"$ & $\prime \prime$ & 1 回と計測する \\
\hline 466 & & 4. No. personal \\
\hline
\end{tabular}

(29頁より)

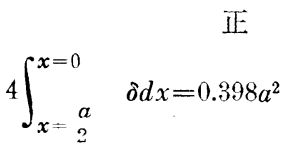

Fig $25 . \quad x>a \quad y<a$

中心の軌跡

の式は附記（2）の最後に来る

表面の粗さが

この測定器で

1 回に計测する

4. No personal 